\title{
The effect of L-glutamine on the genetic transformation of embryogenic cell suspensions of gentian species (Gentiana lutea L., Gentiana cruciata L., and Gentiana kurroo Royle) using Agrobacterium tumefaciens
}

\author{
JAN J. RYBCZYŃSKI ${ }^{1 *}$, ANNA I. WÓJCIK ${ }^{1}$ \\ Polish Academy of Sciences Botanical Garden - Center for Biological Diversity Conservation, Powsin, Warszawa, Poland
}

\begin{abstract}
In this study, established embryogenic cell suspensions of three gentian species, Gentiana cruciata L., Gentiana kurroo Royle, and Gentiana lutea L., cultured in the presence of two media CMS1 and CMS2, were used to determine the effect of L-glutamine on the efficiency of Agrobacterium tumefaciens-mediated transformation. The presence of $1 \mathrm{~g} \cdot \mathrm{l}^{-1}$ glutamine in the co-cultivation medium and a 48-hr co-cultivation period were found to be optimal for all the cultures investigated. In order to regenerate plants in the post-transformation culture, approximately $100 \mathrm{mg}$ of cell aggregates was plated as a single layer on RM1 and RM2 media. Timentin was used in posttransformation cultures for preventing bacterial contamination and enhancing cell viability. The transformants were selected in the presence of $50 \mathrm{mg} \cdot \mathrm{l}^{-1}$ kanamycin. Transformation was later confirmed by histochemical analysis of the activity of reporter enzyme ( $\beta$-glucuronidase) and by polymerase chain reaction for the detection of uidA and nptII genes. Five lines of embryogenic cell suspension cultures of the studied species were selected and grown in the presence of $50 \mathrm{mg} \cdot 1^{-1}$ kanamycin. Finally, 23 embryos were regenerated, of which only 11 converted into T0 transformants of $G$. cruciata. These transformants continued to grow in the presence of kanamycin. A solid, dark blue coloration of their leaves confirmed stable integration and expression of the uidA gene. The molecular analysis of T0 plants revealed the absence of bacterial contamination. Thus, the short list of plant species that can be transformed by $A$. tumefaciens with the help of an embryogenic cell suspension is extended by the three species investigated in this study.
\end{abstract}

Key words: embryogenic cell suspensions, gentians, kanamycin resistance, L-glutamine, timentin, transformants

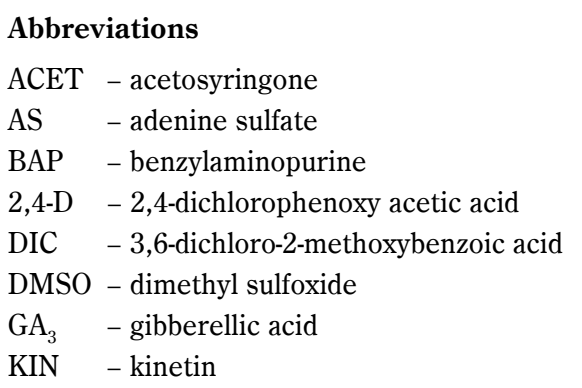

\section{Introduction}

The species belonging to the family Gentianaceae are economically important because of their pharmacological (production of very rich, specific secondary metabolites) and horticultural values (beauty of the flowers and va-

$\begin{array}{ll}\text { MS medium } & \text { - Murashige and Skoog medium (1962) } \\ \text { nptII gene } & \text { - neomycin phosphotransferase gene } \\ \text { NAA } & \text { - naphthaleneacetic acid } \\ \text { PCR } & \text { - polymerase chain reaction } \\ \text { PGR } & \text { - plant growth regulator } \\ \text { TIM } & \text { - timentin } \\ \text { uidA (gus) gene } & \text { - glucuronidase gene }\end{array}$

riation in size and shape of the leaves) (Rybczyński et al. 2015). Hence, experimental botanists show continued interest in improving the quality of gentians using different biotechnological methods. Studies on in vitro morphogenesis of the species belonging to the family Gen-

\footnotetext{
* Corresponding author: Polish Academy of Sciences Botanical Garden - Center for Biological Diversity Conservation, Powsin, Prawdziwka 2, 02-973 Warszawa, Poland; e-mail: j.rybczynski@obpan.pl
} 
tianaceae have been undertaken for only a few taxa, with the most popular genus being Gentiana (Rybczyński et al., 2015). The manipulation of plant cells allows for creating efficient new combinations of different genes. At present, modification of the genome of a gentian requires modification of the methods used for the manipulation of its cells. The explant manipulation can be achieved using two approaches: callus formation and establishment of cell suspension. In gentians, two distinct types of callus proliferation are possible which yield nonembryogenic dedifferentiated (a source of secondary metabolites) and embryogenic liquid cell suspensions (a source of somatic embryos) (Chueh et al., 2001). The liquid cell suspension culture of the plant cells allows for any kind of manipulation. Centaurium erythraea was the first species of the family Gentianaceae to be studied for somatic embryogenesis in cell suspension maintained on MS medium in the presence of KIN, together with IAA and 2,4-D (Barešová and Kaminek, 1984). Species of the taxa Gentiana were selected more often than others for studies on somatic embryogenesis in cell suspension. Various combinations of PGRs, including 2,4-D + KIN or $\mathrm{NAA}+\mathrm{BAP}+\mathrm{DIC}+\mathrm{AS}$, were used for successful induction of embryogenic proliferation of a leaf blade tissue that originated from the plant axenic culture and various explants of a 10-day-old seedling (Ruffoni and Massabò, 1996; Mikuła et al., 2005; Fiuk and Rybczyński, 2008; Mikuła et al., 2011).

In the case of gentians, all traditional methods of plant cell transformation have been explored including particle bombardment and electroporation. However, the majority of the papers published thus far have only described the application of leaf tissues or seedling explants for transformation using bacteria Agrobacterium rhizogenesis and Agrobacterium tumefaciens. To date, a vector transformation system using $A$. tumefaciens has been developed for the following members of the family Gentianaceae: Eustomagrandiflorum(EHA115 pKIWI105 or pSW9), Gentiana dahurica(GV3130 pBI121), Gentiana punctata (C58C1 pArA4b), Gentiana triflora $\times$ Gentiana scabra cv. Polano-White (EHA 105 pEKB35SGtMADSbar or pSMAB-rolCGtMADS4), and G. triflora $\times$ G. scabra cv. Polano-White (pSM MARB-rolCproFT) and cv. Albireo (EHA 101 pSMABsCHS). Post-transformation cultures involving the regeneration of transformants of $G$. triflora $\times G$. scabra hybrids were based on shoot regeneration of a callus resistant to various selection agents in the pre- sence of TDZ and NAA (Hosokawa et al., 2000; Semeria et al., 1995; Wójcik and Rybczyński, 2015; Semeria et al., 1996; Mishiba et al., 2006; Mishiba et al., 2005; Nishihara et al., 2006; Nakatsuka et al., 2009; Sun and Meng, 2010).

In the majority of previously published studies on gentian transformation, fragments of plant material or even entire axenic plants were selected for experiments. In gentians, a very high production of antimicrobial metabolites is thought to occur in differentiated plant tissues characterized by a low rate of mitotic activity of cells. Some studies have reported that following a 7-daylong subculture (Mikuła et al., 2011; Fiuk and Rybczyński, 2008; Ruffoni and Massabò, 1996), embryogenic cell suspensions were characterized by a high rate of mitotic activity and a low production of secondary metabolites. These results gave us hope that this approach would be highly efficient for gentian transformation.

The embryogenic cell suspensions were utilized in vector transformation experiments in species belonging to different taxonomic clades, for example, Carica papaya, Hordeum vulgare, Nicotiana tabacum, Santalum album, and four species of Taxus taxa (Ketchum et al., 2007; Shekhawat et al., 2008; Kim et al., 2004; Wu et al., 1998; Carlos-Hilario and Christopher, 2015; Wilson et al., 2018). Owing to its economic value, special attention was paid to the transformation of embryogenic cell suspension of various cultivars of Musa acuminata, such as "Mas", "Rasthali", "Robusta" and "Dwarf Caven" (Ganapathi et al., 2001; Huang et al., 2007; Chee Wong et al., 2008; Ghosh et al., 2009; Chong-Rerez et al., 2012).

A number of attempts have been undertaken to increase the efficiency of transformation by the application of various factors (chemicals) such as amino acids. In these experiments, amino acids have played a dual role by directly improving the transformation efficiency, and as already described (Amstrong and Green, 1985; Chowdhary et al., 1993), supporting the somatic embryogenesis in cultures of various species belonging to different plant families (Shetty and McKersie, 1993; Malabadi and Van Staden, 2005; Zouine and Hadrami, 2007; Gerdakaneh et al., 2011; Pawar et al., 2015). Dan (2008) demonstrated that the use of antioxidants (glycine, betaine, glutathione, and polyvinylpyrrolidone) accelerated transformation. Much effort was also devoted to improving the transformation efficiency of Citrus aurantifolia (Dan et al., 2008) and other crops (Dong and McHughen, 1993). 
There are numerous plant species in which the involvement of amino acids in induction and establishment of various types of cultured calli tissues and cell suspensions derived from them has been described. In these cases, organic nitrogen was used to support the growth of the tissues cultured in artificial (in vitro) conditions and to control the morphogenic processes. Amino acids such as L-alanine, L-proline, L-glutamine, L-asparagine, and L-tryptophan were used individually (Haroun et al. 2010; Gerdakaneh et al. 20110) or in combinations (Garin et al., 2000; Malabadi and van Staden, 2005). Additionally, some of the amino acids including L-glutamine have been used for improving the efficiency of Agrobacterium transformation.

In the case of leaf blade explants of Gentiana cruciata, L-glutamine was used as an essential factor for obtaining callus tissue and ensuring stable transformation. The highest number of $\mathrm{T} 0$ plants was regenerated in the presence of $1 \mathrm{~g} \cdot 1^{-1} \mathrm{~L}$-glutamine (Wójcik and Rybczyński, 2017). Based on our experience with vector (Wójcik and Rybczyński, 2017) and nonvector (Wójcik and Rybczyński, 2015) transformations of gentians, complexes of (mitotically active) embryogenic cells were selected for the experiments conducted in the present study to test the effect of L-glutamine on transformation efficiency and maintenance of embryogenic potential. Thus, the aim of this study was to investigate the effects of L-glutamine on the efficiency of Agrobacterium-mediated transformation of the established cell suspensions of three gentian species, namely G. cruciata, Gentiana kurroo, and Gentiana lutea. A. tumefaciens strain $\mathrm{C} 58 \mathrm{C} 1$ carrying $n p t I I$ and uidA genes was used as a vector. The transformation system used in this study was based on the liquid co-culture of plant cell aggregates with bacterial cells in the presence of L-glutamine. Additional effort was made to remove bacterial cells from the suspension during all steps of the post-transformation procedure and from regeneration cultures in order to obtain a bacteria-free culture. The cultures resulted in the formation of somatic embryos and regeneration of $\mathrm{T} 0$ transformants. Unfortunately, we only present the description of $\mathrm{T} 0$ here since the environmental protection law currently binding in Poland forbids carrying out experiments on genetically modified organisms outside the laboratory. Being perennials, gentians need to be grown in field for a few years in order for them to attain sufficient development to produce next sexual generation, which is required for understanding the entire transgenesis process.

\section{Materials and methods}

\section{Cell suspension culture}

Three well-established cell suspensions of $G$. cruciata L. (cotyledon origin), G. kurroo Royle (cotyledon derived), and G. lutea L. (seedling root origin) maintained in $200 \mathrm{ml}$ conical flasks were used for the experiments. Cultures were maintained in liquid MS media supplemented with (1) $0.5 \mathrm{mg} \cdot 1^{-1} 2,4-\mathrm{D}+1 \mathrm{mg} \cdot 1^{-1} \mathrm{KIN}$ (CSM1) or (2) $2 \mathrm{mg} \cdot 1^{-1} \mathrm{BAP}+1 \mathrm{mg} \cdot 1^{-1} \mathrm{DIC}+0.1 \mathrm{mg} \cdot 1^{-1} \mathrm{NAA}$ $+80 \mathrm{mg} \cdot 1^{-1} \mathrm{AS}$ (CSM2) (Table 1). Both the media were supplemented with $30 \mathrm{~g} \cdot 1^{-1}$ sucrose, and the $\mathrm{pH}$ was adjusted to 5.6 before autoclaving. The cultures were placed on a rotary shaker at $120 \mathrm{rpm}$ and kept in a growth chamber at $22 \pm 1^{\circ} \mathrm{C}$ under illumination of $3.5 \mu \mathrm{Em}^{-2} \mathrm{~s}^{-1}$. Subculturing was done weekly using cells in exponential growth. The growth of cell suspension culture was documented by photographs taken using Olympus microscopes and cameras.

\section{Agrobacterium tumefaciens culture}

Agrobacterium tumefaciens cells were maintained in a YEB agar medium $\left(5 \mathrm{~g} \cdot \mathrm{l}^{-1}\right.$ peptone, $5 \mathrm{~g} \cdot \mathrm{l}^{-1}$ yeast extract, $1 \mathrm{~g} \cdot \mathrm{l}^{-1}$ beef extract, $0.49 \mathrm{~g} \cdot \mathrm{1}^{-1} \mathrm{MgSO}_{4}$ with or without $15 \mathrm{~g} \cdot \mathrm{l}^{-1}$ agar, $\mathrm{pH}=7.2$ ). Two-day-old subcultures of individual colonies of bacteria were resuspended in small volumes of YEB medium and were subsequently transferred to a fresh liquid YEB medium for multiplication. These cultures were maintained for $24 \mathrm{hrs}$ in the dark at $28^{\circ} \mathrm{C}$ on a rotary shaker at $180 \mathrm{rpm}$. Just prior to the experiment, the bacteria were collected and washed three times using sterile $10 \mathrm{mM} \mathrm{MgSO}$ by centrifugation. Finally, they were transferred to the inoculation medium (IM3) (Table 2) with $\mathrm{OD}=0.8$ at $\lambda=600 \mathrm{~nm}$.

\section{Kanamycin (selection agent) concentration testing for cell aggregate elimination}

Different concentrations of kanamycin $(0,50,100$, 150,200 , and $250 \mathrm{mg} \cdot 1^{-1}$ ) were tested for evaluating the survival and selection of $1 \mathrm{~g}$ of G. cruciata and G. kurroo cell suspension cultured in $30 \mathrm{ml}$ of liquid CSM1 and CSM2 media. The experiment comprised five replicates. Four-week-old cultures were used. Visual changes and total fresh and dry weights of samples were examined for evaluating the response of cultured aggregates. 
Table 1. Media used for cell suspension culture

\begin{tabular}{c|c|c}
\hline Medium & \multicolumn{1}{|c|}{ Content } & Application \\
\hline CSM1 & $\mathrm{MS}+0.5 \mathrm{mg} \cdot \mathrm{l}^{-1} 2,4-\mathrm{D}+1.0 \mathrm{mg} \cdot \mathrm{l}^{-1} \mathrm{KIN}+30 \mathrm{~g} \cdot \mathrm{l}^{-1} \mathrm{sucrose}$ & Media used for cell \\
CSM2 & $\mathrm{MS}+2.0 \mathrm{mg} \cdot \mathrm{l}^{-1} \mathrm{BAP}+1.0 \mathrm{mg} \cdot \mathrm{l}^{-1} \mathrm{DIC}+0.1 \mathrm{mg} \cdot \mathrm{l}^{-1} \mathrm{NAA}+80 \mathrm{mg} \cdot \mathrm{l}^{-1} \mathrm{SA}+30 \mathrm{~g} \cdot \mathrm{l}^{-1}$ sucrose & suspension culture \\
\hline
\end{tabular}

A

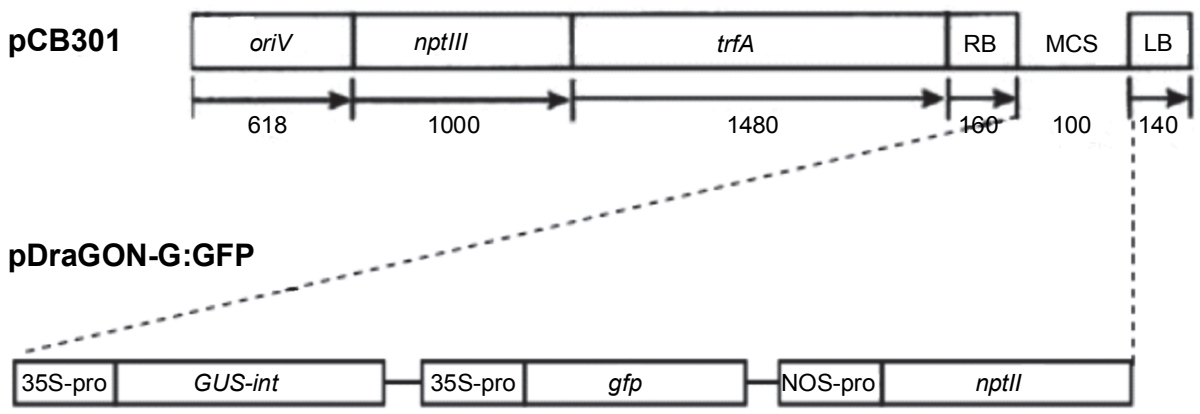

B

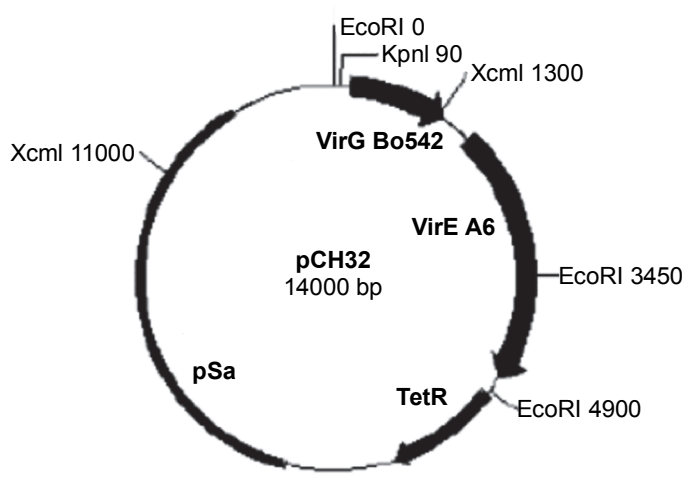

C

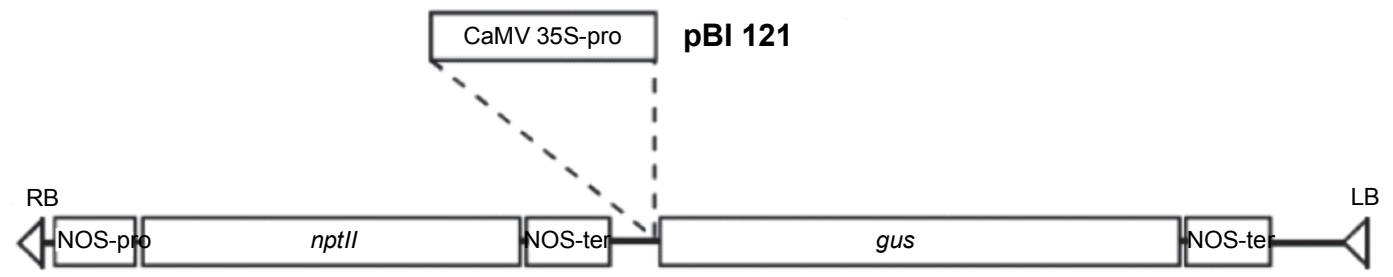

pBI 101

Schema 1. Map of the plasmids used for an efficient transformation of gentian cell suspensions. A) pCB301 (Xiang et al., 1999) and vector pDraGON-G:GFP; B) helper plasmid pCH (Hamilton, 1997) (www.biotech.cornell.edu); C) fragment of T-DNA plasmid pBI 121 (Jefferson et al., 1987) (RB/LB - right/left border; MCS - polylinker (multiple cloning site); gus - $\beta$-glucuronidasecoding gene; $n p t I I$ and $n p t I I I$ - neomycin phosphotransferase-coding genes (kanamycin resistance); $g f p$ - green fluorescence protein-coding gene; 35S-pro (CaMV 35S pro) - Cauliflower Mosaic Virus promoter; NOS-pro/NOS-ter - promoter/terminator of nopalin synthase gene; oriV and trfA - part of ori replication of RK2 plasmid; pSa - ori replication of PSa plasmid; TetR

- resistance for tetracycline; virV and virG genes - Agrobacterium genes responsible for vir activation and T-DNA transfer 
Table 2. Media used for transformation of embryogenic cell suspension with Agrobacterium tumefaciens

\begin{tabular}{|c|c|c|}
\hline Medium & Content & Application \\
\hline IM3 & $\begin{array}{l}\text { MS + PGR used for particular cell suspension + ACET + } 0 ; 0.25 ; 0.5 ; 1.0 \text {; } \\
2.0 \mathrm{~g} \cdot 1^{-1} \text { GLN }\end{array}$ & $\begin{array}{l}\text { Media used for cell suspension in- } \\
\text { cubation with Agrobacterium } \text { C58C1 }\end{array}$ \\
\hline AEM1 & MS + PGR used for particular cell suspension $+30 \mathrm{~g} \cdot \mathrm{l}^{-1}$ sucrose + TIM & $\begin{array}{l}\text { Medium for Agrobacterium elimina- } \\
\text { tion from transgenic cell suspension }\end{array}$ \\
\hline SM1 & $\begin{array}{l}\text { MS + PGR used for particular cell suspension }+30 \mathrm{~g} \cdot 1^{-1} \text { sucrose }+ \text { TIM } \\
+ \text { KAN }\end{array}$ & $\begin{array}{l}\text { Medium for transgenic cell suspen- } \\
\text { sion aggregate selection }\end{array}$ \\
\hline RM1 & $\begin{array}{l}\mathrm{MS}+1.0 \mathrm{mg} \cdot 1^{-1} \mathrm{KIN}+0.5 \mathrm{mg} \cdot 1^{-1} \mathrm{GA}_{3}+80 \mathrm{mg} \cdot \mathrm{l}^{-1} \mathrm{AS}+30 \mathrm{~g} \cdot \mathrm{l}^{-1} \text { sucrose } \\
+\mathrm{KAN}+\text { agar }\end{array}$ & \multirow{2}{*}{$\begin{array}{l}\text { Medium for genetically modified re- } \\
\text { generants regeneration from trans- } \\
\text { formed cell suspension }\end{array}$} \\
\hline RM2 & $\mathrm{MS}+30 \mathrm{~g} \cdot \mathrm{l}^{-1}$ sucrose $+\mathrm{KAN}+$ agar & \\
\hline TPM & $\mathrm{MS}+30 \mathrm{~g} \cdot \mathrm{l}^{-1}$ sucrose $+\mathrm{KAN}+$ agar & $\begin{array}{l}\text { Medium for tranformants in vitro cul- } \\
\text { ture }\end{array}$ \\
\hline
\end{tabular}

For a better analysis of tissue response to kanamycin, additional experiments on agar medium were carried out only for the cell suspension of $G$. cruciata using RM1 medium (Table 2$)$. Cell aggregates (100 mg) were plated onto medium (six replicates). Subculturing was performed fortnightly. After 8 weeks of culturing, the effect of the antibiotic on the growth of cell aggregates was evaluated by measuring the number of somatic embryos regenerated, together with the fresh weight of tissue. For subsequent subcultures on liquid and agar medium, only $50 \mathrm{mg} \cdot \mathrm{l}^{-1} \mathrm{kanamycin}$ was used for transgenesis selection.

\section{Effect of L-glutamine on transformation efficiency}

In order to ascertain the effect of L-glutamine on transformation of cell aggregates, filter-sterilized L-glutamine at concentrations ranging from 0 to $2 \mathrm{~g} \cdot 1^{-1}$ was used. The time of treatment of cell suspension was correlated with the time of co-culture of the plant material with bacteria for 24 and $48 \mathrm{hrs}$.

\section{Transformation of embryogenic cell suspension aggregates}

One gram of cell aggregates collected from the suspension on sterile nylon sieves at the beginning of the logarithmic phase of the growth curve was transferred to a conical flask $(100 \mathrm{ml})$ and resuspended in $30 \mathrm{ml}$ of bacterial inoculum. Co-cultures were incubated for 24 and 48 hrs. Later, cultures were washed with sucrosefree media: CSM1 or CSM2 (Table 1). Aggregates were subsequently cultured with AEM1 medium (along with TIM) for 1 week in order to eliminate the bacteria. Finally, the cultures were transferred to SM1 liquid medium for kanamycin selection. After 2 weeks of cultu- ring, the transformation efficiency was assessed by analyzing the expression of $\beta$-glucuronidase reporter gene. Transformation efficiency was expressed in terms of number of dark and light blue-stained cell aggregates visible under a light microscope in a sample of 50 aggregates. For the next 3 months, cell suspensions were cultured under selection using $50 \mathrm{mg} \cdot \mathrm{l}^{-1}$ kanamycin. Following this period (i.e. 16 weeks after the transformation experiment), the cultures were evaluated for the second time using the GUS histochemical assay and subjected to a molecular analysis.

\section{Post-transformation cell suspension cultures and plant regeneration (transformants TO)}

In order to aid plant regeneration in the post-transformation culture, following 4 weeks of selection, approximately $100 \mathrm{mg}$ of cell aggregates was plated as a single layer on RM1 and RM2 (Table 2) agar-solidified media. Subcultures were carried out at fortnightly until somatic embryos became apparent. The conversion of somatic embryos into plantlets (germlings) was carried out on TPM medium containing kanamycin. On this medium, regenerated plantlets developed root systems and produced numerous leaves which served as material for further histochemical analyses of GUS and for PCR for confirming transformation.

\section{Assay of GUS activity}

The expression of GUS in cells, calluses, and leaf fragments of transformants was assayed using 5-bromo-4chloro-3-indolylglucuronide (X-Gluc) as substrate. Tissues were incubated in a reaction mixture comprising $1 \mathrm{mM}$ of substrate in DMSO, $20 \mathrm{mM}$ phosphate buffer 
$(\mathrm{pH}=7.0), 0.25 \mathrm{mM}$ Triton $\mathrm{X}-100$, and $3.12 \mathrm{mM}$ methanol. The plant material was immersed in reaction mixture and kept at $37^{\circ} \mathrm{C}$ for $24 \mathrm{hrs}$ in the dark. Following this, the plant material was treated with $70 \%$ ethanol three times to extract chlorophyll from tissues, so that the blue (dichloro-dibromoindigo) coloration due to GUS reaction could be seen. Finally, the tissues were fixed with Carnoy's fixative (acetic acid:ethanol in the ratio of $1: 3)$. The expression of GUS in cells was investigated twice: at the second and the $12^{\text {th }}$ week post-transformation. For the second investigation, only 50 aggregates of each cell suspension, which survived kanamycin selection, were used (Table 3).

\section{PCR analysis of transgenesis}

The transgenic events were confirmed by carrying out PCR of both $n p t I I$ and uidA genes. The following forward and reverse primers were used for nptII gene: 5'-GAGGCTATTCGGCTATGACTG- ${ }^{\prime}$ ' and $5^{\prime}$-ATCGG GAGCGGCGATACCGTA- $3^{\prime}$, respectively; these primers amplified a fragment of 700 bp (Wójcik and Rybczyński, 2017). The thermal profile adopted for PCR was as follows: pre-denaturation at $95^{\circ} \mathrm{C}$ for $15 \mathrm{~min}$, followed by 30 cycles of denaturation at $94^{\circ} \mathrm{C}$ for $30 \mathrm{sec}$, annealing at $56^{\circ} \mathrm{C}$ for $30 \mathrm{sec}$, and elongation at $72^{\circ} \mathrm{C}$ for $60 \mathrm{sec}$; this was followed by a final extension at $72^{\circ} \mathrm{C}$ for $5 \mathrm{~min}$ and a pause at $4{ }^{\circ} \mathrm{C}$. For uidA gene, the following forward and reverse primers were used: $5^{\prime}$-TTATCTCTATGAA CTGTGCGTCA- $3^{\prime}$ and $5^{\prime}$-TTGGACATACCATCCGTAA TAA- $3^{\prime}$, respectively; these primers amplified a fragment of $679 \mathrm{bp}$. The primers were designed using the Primer3 program on the basis of sequences of uidAgene found in the NCBI database. The following thermal profile was adopted for PCR: pre-denaturation at $95^{\circ} \mathrm{C}$ for $15 \mathrm{~min}$, followed by 30 cycles of denaturation at $94^{\circ} \mathrm{C}$ for $30 \mathrm{sec}$, annealing at $51^{\circ} \mathrm{C}$ for $1 \mathrm{~min}$, and elongation at $72^{\circ} \mathrm{C}$ for $2 \mathrm{~min}$; this was followed by a final extension at $72^{\circ} \mathrm{C}$ for $10 \mathrm{~min}$ and a pause at $4{ }^{\circ} \mathrm{C}$.

\section{Statistical analysis}

Statistical analysis was performed using Statgraphics Plus4.1 program.

\section{Results}

\section{Evaluation of the effect of kanamycin concentration on cell suspension growth}

The effect of kanamycin on the growth of cell suspension was studied at concentrations ranging between
0 and $250 \mathrm{mg} \cdot 1^{-1}$. The toxic effect of kanamycin on the growth and development of cells was evaluated in terms of both fresh and dry mass of culture. The lowest concentration of kanamycin $\left(50.0 \mathrm{mg} \cdot \mathrm{l}^{-1}\right)$ appeared to be the most critical one because it reduced the biomass by fivefold in all the investigated cell suspensions. In contrast, higher concentrations $\left(100.0-250.0 \mathrm{mg} \cdot \mathrm{l}^{-1}\right)$ caused quicker degradation of suspensions and appearance of necrotic spots in aggregates grown on the agar medium. Figure 1 shows the response of cell suspension of G. cruciata as an example of the toxic effect of kanamycin on the growth of gentian cells. The media supplemented with various PGRs did not show any increase in the survival rate even when kanamycin was present at $50.0 \mathrm{mg} \cdot 1^{-1}$.

\section{Transient expression of gus gene in cell aggregates}

The histochemical analysis of the expression of the reporter gus gene in cell aggregates was used as the main tool for evaluating the transient expression in cell suspensions. One criterion that was considered for this analysis was dark vs. pale blue staining of cells. Following the incubation of the cell suspension with Agrobacterium and TIM, transformation was evaluated in the presence of the selection agent kanamycin $\left(50 \mathrm{mg} \cdot \mathrm{l}^{-1}\right)$ (Table 3).

\section{Transformation of G. lutea cell suspension}

In the case of cell suspension of G. lutea (Fig. 2), the presence of L-glutamine in the co-culture medium was found to have the greatest effect on the transformation efficiency. The highest transformation frequency of $25 \%$ occurred at the concentration of $1 \mathrm{~g} \cdot \mathrm{l}^{-1}$ of L-glutamine. Under this condition, a strong staining of cell aggregates due to gus gene expression was observed in $17 \%$ of the total scored aggregates. At lower $\left(0.5 \mathrm{~g} \cdot \mathrm{l}^{-1}\right)$ and higher $\left(2 \mathrm{~g} \cdot \mathrm{l}^{-1}\right)$ concentrations of glutamine, the transient expression was $20 \%$ and $21 \%$, respectively, which was not significantly different (Fig. 3A). The strongest gus gene expression was observed when the medium was supplemented with $2 \mathrm{~g} \cdot 1^{-1} \mathrm{~L}$-glutamine; however, the aggregates did not survive the selection pressure at $50 \mathrm{mg} \cdot 1^{-1}$ kanamycin. Only aggregates that transformed in the presence of $1 \mathrm{~g} \cdot \mathrm{l}^{-1} \mathrm{~L}$-glutamine survived kanamycin selection and continued to show meristematic activity which led to the growth of transformed cells during the next 3 months (Table 4). Finally, only one cell line was developed. 

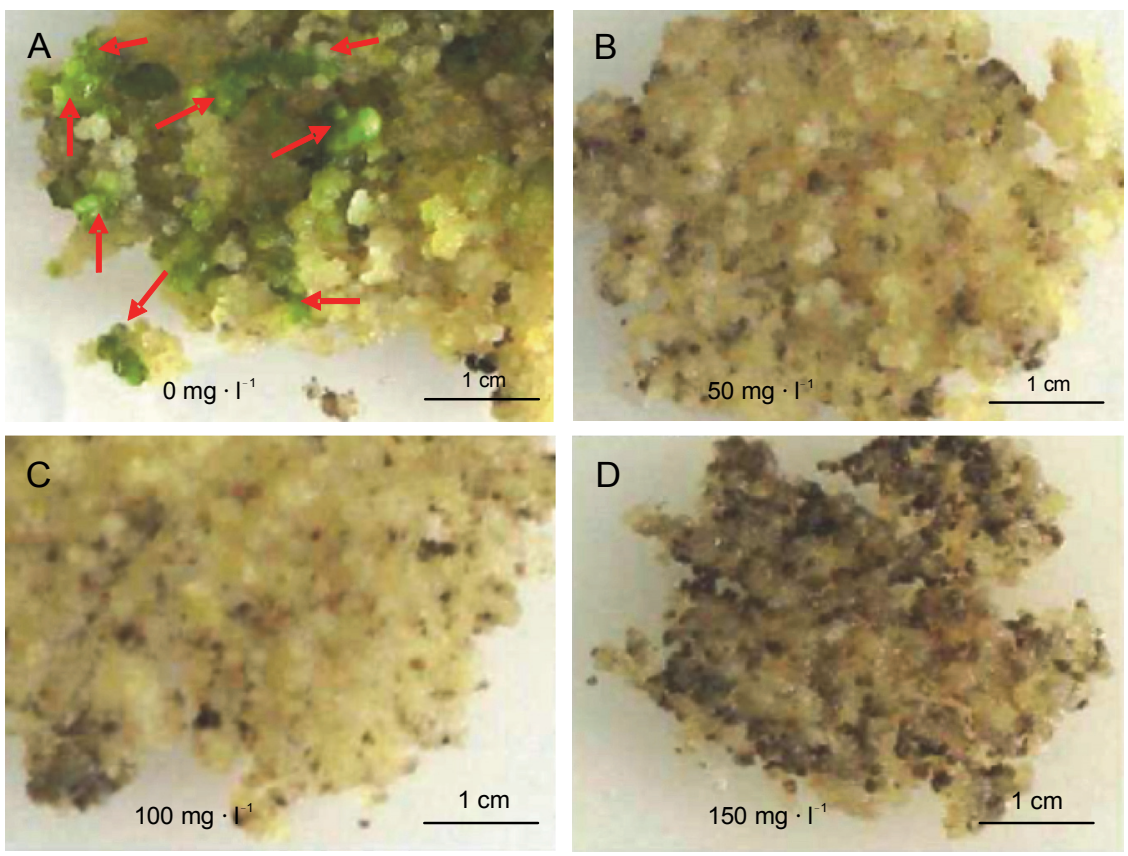

Fig. 1. The necrotic response of Gentiana cruciata cell suspension in the presence of increasing concentration of kanamycin; brown spots represent the necrotic cell aggregates on SM1 agar medium; red spots present somatic embryo formation

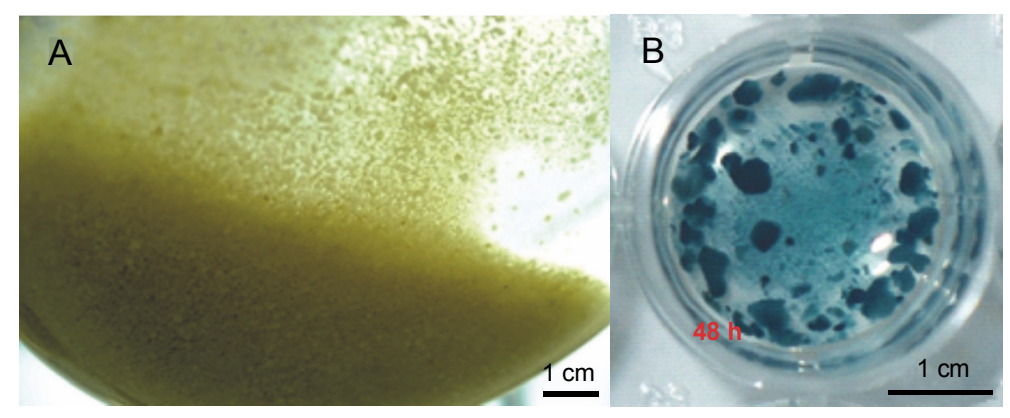

Fig. 2. Embryogenic cell suspension of Gentiana lutea. A) established 6-month-old embryogenic cell suspension in CSM1 liquid medium in conical flask; B) $\beta$-glucuronidase expression in modified line of cell aggregates observed after 3 months of culture; Agrobacterium transformation was done during $48 \mathrm{hrs}$ in the presence of $1.0 \mathrm{~g} \cdot \mathrm{l}^{-1} \mathrm{~L}$-glutamine

\section{Transformation of G. kurroo cell suspension}

Cell suspensions of $G$. kurroo were found to be more sensitive to Agrobacterium transformation and to incubation in the absence of any transformation agent, as only $8 \%$ of cell aggregates showed a positive GUS expression. Supplementing the co-cultivation medium with $0.25 \mathrm{~g} \cdot \mathrm{1}^{-1}$ L-glutamine increased the number of blue-stained aggregates, but the increase was insignificant. The most effective concentration of L-glutamine appeared to be $2 \mathrm{~g} \cdot \mathrm{1}^{-1}$, at which $37 \%$ of aggregates (Fig. 3 and Fig. 3B) were successfully stained, although the differences in the staining observed between 2 and $1 \mathrm{~g} \cdot \mathrm{l}^{-1}$ L-glutamine were statistically insignificant. Compared to G. lutea, the percentage of strongly stained aggregates was higher at both concentrations. As described for the cell suspension of $G$. lutea, only the cell line established in the presence of $1 \mathrm{~g} \cdot \mathrm{1}^{-1} \mathrm{~L}$-glutamine was able to survive the selection pressure at $50 \mathrm{mg} \cdot 1^{-1}$ kanamycin and develop a transgenic cell line (Table 4 ). Finally, only one cell line was established. 
A

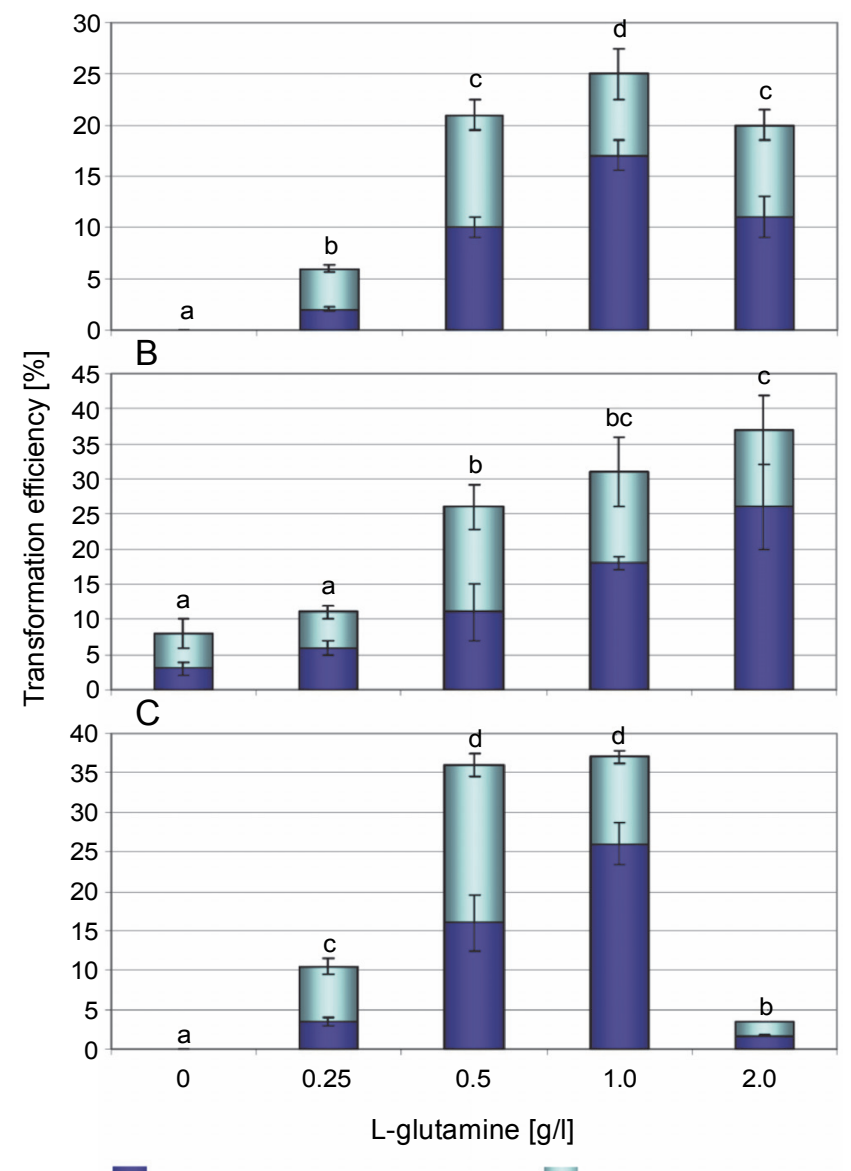

Intensively stained aggregates

Lightly stained aggregates

Fig. 3. The effect of L-glutamine on the efficiency of aggregate transformation analyzed after 14 days of culturing following transformation (the same letters are not significantly different at $P>0.05)$. A) transformation efficiency of Gentiana lutea; B) transformation efficiency of Gentiana kurroo; C) transformation efficiency of Gentiana cruciata

\section{Transformation of G. cruciata cell suspension}

Similar to the other two cell suspensions, the amino acid L-glutamine was found to improve the transformation efficiency of cell suspension of $G$. cruciata. In the presence of L-glutamine at the four concentrations studied, the reporter gene expression was evaluated at both 24 and 48 hrs of co-culture. No transient expression of GUS was found in the control culture. The highest frequency of transformation (37\%) was observed in the presence of $1 \mathrm{~g} \cdot 1^{-1} \mathrm{~L}$-glutamine compared with $0.5 \mathrm{mg} \cdot \mathrm{l}^{-1}$; however, the difference between the frequencies was insignificant. In the presence of $0.25 \mathrm{~g} \cdot 1^{-1} \mathrm{~L}$-glutamine, only $10.5 \%$ of aggregates expressed transient blue staining, of which only $3 \%$ showed strong expression. The lowest level of transient expression (3.5\%) was observed at the concentration of $2 \mathrm{~g} \cdot \mathrm{l}^{-1}$ of L-glutamine following $48 \mathrm{hrs}$ of co-cultivation. This long duration of co-culture changed the response of cell aggregates, including the bursting of external cells and the browning of aggregates, leading to the death of the culture. The transient expression remained unaffected by various combinations of PGRs that were used to supplement the basal medium (CSM1 and CSM2) (Table 2, Fig. 3C and Fig. 5).

The size of the cell aggregates was not found to have any effect on $\beta$-glucuronidase activity. The reduction of period of exposure to L-glutamine to $24 \mathrm{hrs}$ reduced the transformation efficiency from 37 to $27 \%$ at the concentration of $1 \mathrm{~g} \cdot 1^{-1}$. A significant reduction in the number of blue-stained aggregates (from 36 to $16 \%$ ) was observed in the medium containing $0.5 \mathrm{~g} \cdot 1^{-1} \mathrm{~L}$-glutamine. For both the periods of co-culture ( 24 and $48 \mathrm{hrs)}$ ), a higher percentage of strong blue GUS staining was found in the presence of $1 \mathrm{~g} \cdot \mathrm{l}^{-1} \mathrm{~L}$-glutamine (Fig. 3B). Shortening the incubation period improved the survival of cell aggregates. Genetically modified cell lines of $G$. cruciata showed a stable $\beta$-glucuronidase activity and were developed from cells incubated with $1 \mathrm{~g} \cdot 1^{-1} \mathrm{~L}$-glutamine for 24 and $48 \mathrm{hrs}$ or $0.5 \mathrm{~g} \cdot 1^{-1}$ L-glutamine for $24 \mathrm{hrs}$. Finally, three cell lines were established (Table 3 ).

\section{Plant regeneration from transformed cell lines}

Many cell aggregates were found to be stained blue (evidence of transient expression), but very few produced transgenic lines. In the case of both $G$. kurroo and $G$. lutea, only one transgenic line was established. In the presence of $1 \mathrm{mg} \cdot 1^{-1} \mathrm{KIN}, 0.5 \mathrm{mg} \cdot \cdot^{-1} \mathrm{GA}_{3}$, and $80 \mathrm{mg} \cdot \mathrm{l}^{-1} \mathrm{AS}+50 \mathrm{mg} \cdot \mathrm{l}^{-1}$ kanamycin (RM4 medium), the transgenic lines of G. lutea and G. kurroo lost their morphogenic potential. In the case of $G$. cruciata, three transgenic lines were established, of which only one had morphogenic potential, which was developed by incubating for $48 \mathrm{hrs}$ in the presence of bacteria and $1 \mathrm{mg} \cdot \mathrm{l}^{-1}$ L-glutamine. While evaluating the morphogenic potential, it was observed that $100 \mathrm{mg} \cdot 1^{-1}$ of transgenic tissue produced $4.6 \pm 1.4$ somatic embryos, which showed 14-fold lower efficiency than the control culture (64.0 \pm 3.2 ). Finally, 23 perfectly formed somatic embryos were collected from the transgenic culture. Eleven germlings or transformants were obtained on a hormone-free RM2 medium supplemented with $50 \mathrm{mg} \cdot \mathrm{l}^{-1}$ kanamycin. All transformants showed gus expression (Fig. 5, Table 4). 

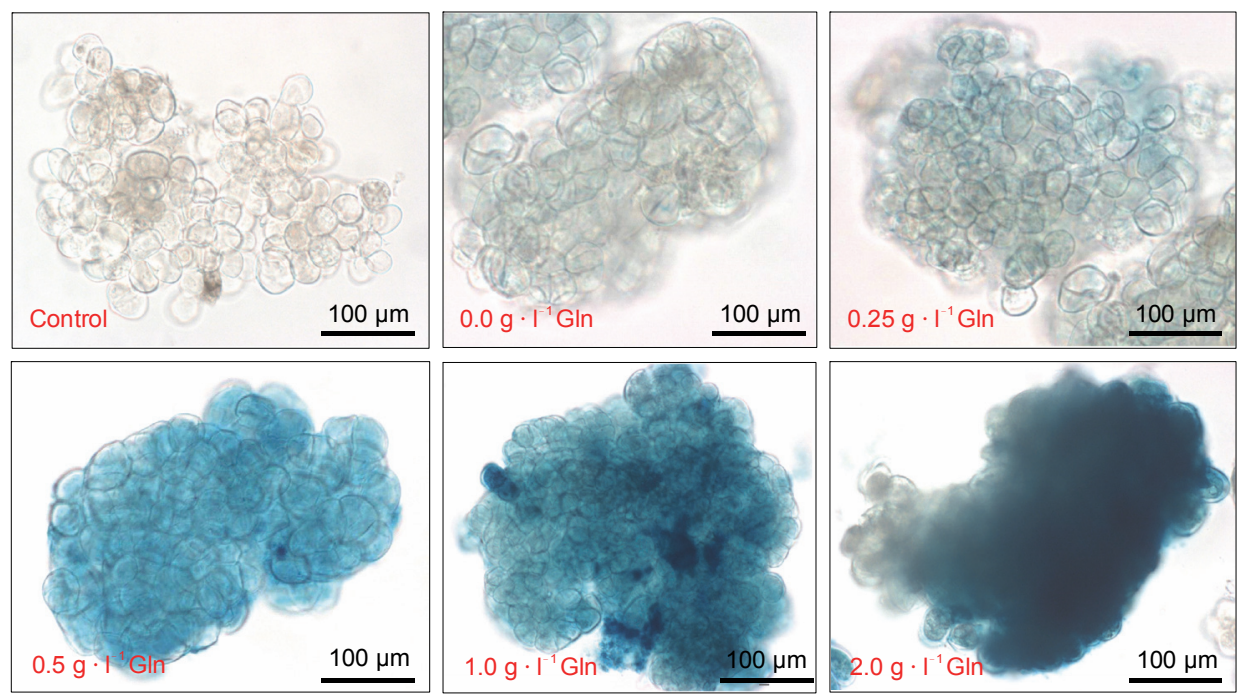

Fig. 4. Histochemical reaction of GUS observed after 14 days following transformation of Gentiana kurroo aggregates with Agrobacterium tumefaciens strain $\mathrm{C} 58 \mathrm{C} 1$ after 48 -hr incubation in the presence of L-glutamine at various concentrations (RM1 medium)
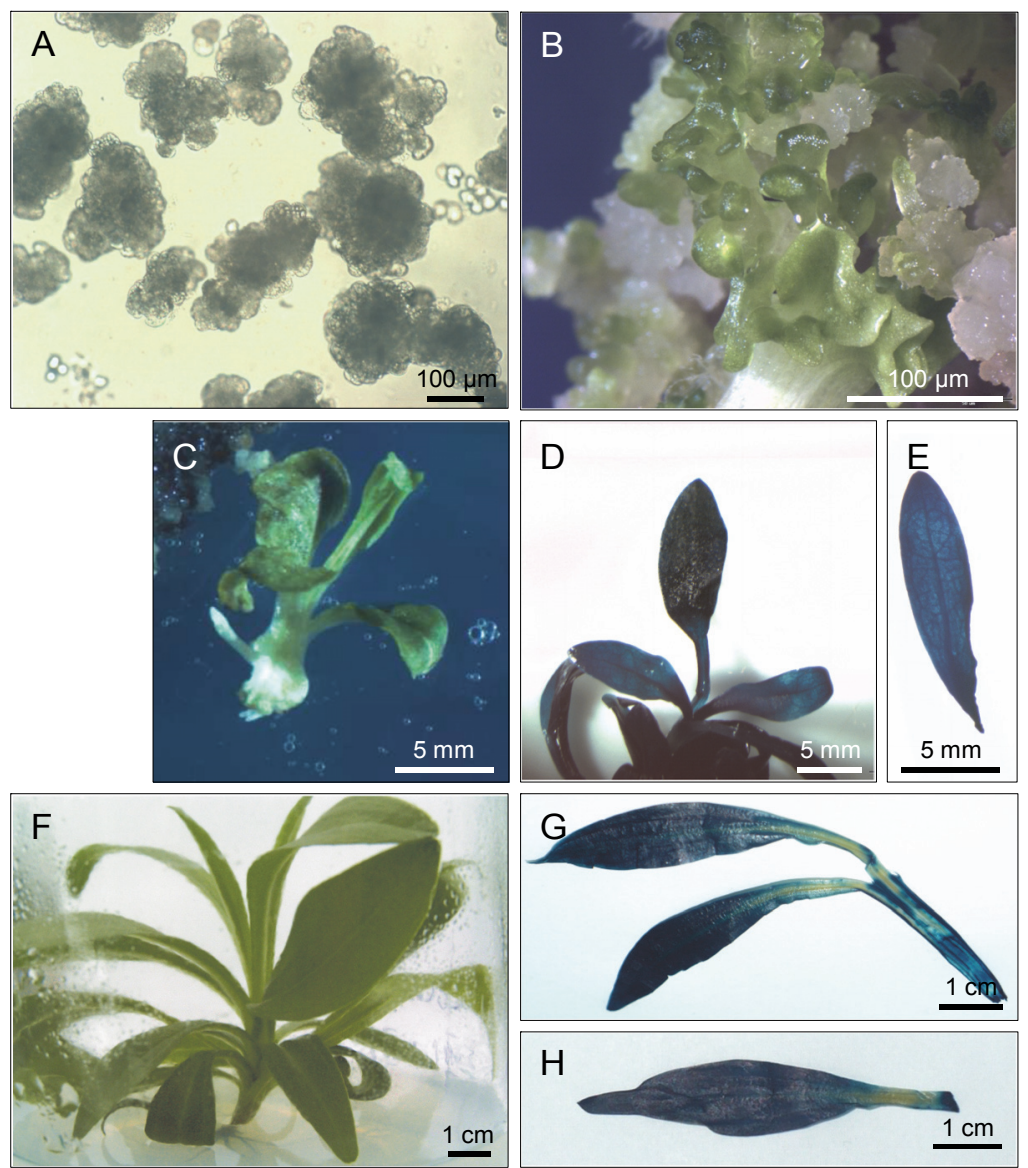

Fig. 5. Stages from transformed embryogenic cell suspension to T0 transformants showing $\beta$-glucuronidase expression (Gentiana cruciata ). A) transgenic cell suspension obtained following 48-h incubation with Agrobacterium tumefaciens carrying C58C1 plasmid in the medium supplemented with $1.0 \mathrm{~g} \cdot \mathrm{l}^{-1}$ glutamine; B) somatic embryo regeneration from transformed cell aggregates (RM1 medium); C) transformant T0 obtained from somatic embryo derived from transformed cell aggregates (RM2 medium); D) regenerated plantlet obtained in the presence of kanamycin following reaction of $\beta$-glucuronidase; E) expression of $\beta$-glucuronidase in the leaf of one of the transformantsT0; F) four-month-old transformant T0 cultured in the presence of kanamycin (RM2 medium); G) and H) intensive blue coloration indicating GUS activity of the lowest leaf and upper leaf whorls of other T0 plants 
Table 3. GUS activity in genetically modified plant material derived from transformation experiments with Agrobacterium tumefaciens $\mathrm{C} 58 \mathrm{C} 1$

\begin{tabular}{c|c|c|c}
\hline \multirow{2}{*}{ Species } & \multicolumn{1}{|c|}{ Type of material } & $\begin{array}{c}\text { Number of cell aggregates express gus gene } \\
/ \text { total number }\end{array}$ & $\begin{array}{c}\text { Time after transformation } \\
\text { (age of tissue or plants) }\end{array}$ \\
\hline \multirow{3}{*}{ G. cruciata } & embryogenic cell aggregates & $3705 / 22050$ & 2 weeks \\
\cline { 2 - 4 } & regenerated plants & $50 / 50$ & 12 weeks \\
\hline \multirow{2}{*}{ G. kurroo } & \multirow{2}{*}{ embryogenic cell aggregates } & $11 / 11$ & 20 weeks (12 weeks) \\
\cline { 3 - 4 } & & $508 / 2250$ & 2 weeks \\
\hline \multirow{2}{*}{ G. lutea } & \multirow{2}{*}{ cell aggregates } & $50 / 50$ & 12 weeks \\
\cline { 3 - 4 } & & $324 / 2250$ & 2 weeks \\
\hline
\end{tabular}

Table 4. PCR analysis of genetically modified cell suspensions and derived from them plants resistant to kanamycin

\begin{tabular}{|c|c|c|c|c|c|}
\hline \multirow{2}{*}{ Species } & \multirow{2}{*}{ Type of samples } & \multicolumn{3}{|c|}{ Presence of studied genes } & \multirow{2}{*}{$\begin{array}{c}\text { Total number of sample studied } \\
\text { with PCR }\end{array}$} \\
\hline & & nptII & uid $A$ & $\operatorname{vir} G$ & \\
\hline \multirow{2}{*}{ G. cruciata } & embryogenic cell aggregates & \multicolumn{2}{|c|}{3 cell lines } & \multirow{4}{*}{ lack } & 3 cell lines \\
\hline & regeneration plants & \multicolumn{2}{|c|}{11 plantlets } & & 11 plants \\
\hline G. kurroo & embryogenic cell aggregates & \multicolumn{2}{|c|}{1 cell line } & & 1 cell line \\
\hline G. lutea & cell aggregates & \multicolumn{2}{|c|}{1 cell line } & & 1 cell line \\
\hline
\end{tabular}

\section{DNA analysis of kanamycin-resistant cell suspensions and TO plants}

The five transformed cell suspension lines which originated from the three plant species studied expressed both the nptII and uidA genes. The PCR analysis also showed the elimination of Agrobacterium contamination and confirmed the presence of $n p t I I$ and uidA genes in all the 11 regenerated transformants. The DNA of these plants did not have the virG gene, and therefore, transformants were confirmed to be free of $A$. tumefaciens contamination (Fig. 6).

\section{Discussion}

The establishment and maintenance of embryogenic cell suspensions of various species of the genus Gentiana has been our focus for many years, as this type of culture provides an excellent material for cryopreservation of cell suspensions (Mikuła et al., 2011), protoplast culture (Fiuk and Rybczyński, 2007; Tomiczak et al., 2015), somatic hybridization (Tomiczak et al., 2015; Tomiczak et al., 2017), protoplast electroporation (Wójcik and Rybczyński, 2015), and plant gene manipulation including vector transformation. Gentians represent one

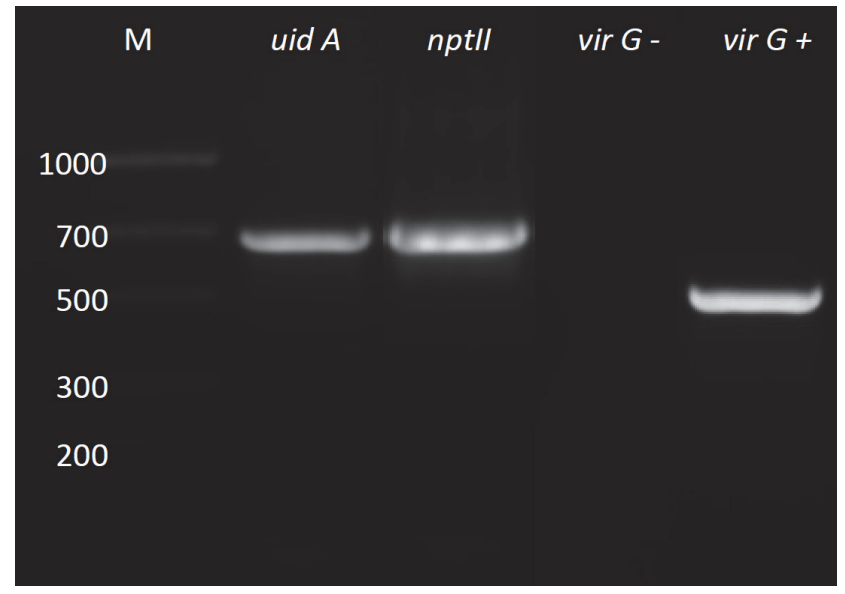

Fig. 6. PCR analysis of transgenic gentians which did not express virGgene: virG--Agrobacterium tumefaciens contamination; vir $G^{+}-$positive control ( $A$. tumefaciens DNA)

of the richest sources of secondary metabolites in the plant world, and their products possess a strong and broad-spectrum antibacterial activity (Hosokawa et al., 2000). Due to this reason, Agrobacterium transformation of gentians appears promising for the maintenance of embryogenic potential. The present paper supplements our knowledge of the morphogenic potential of 
gentian cells in stress conditions in the presence of the Agrobacterium co-culture. In this paper, we describe for the first time the Agrobacterium-mediated transformation of embryogenic cell suspensions derived from selected members of the family Gentianaceae. Until now, only one paper on transformation of proliferating cell suspension culture of gentians has been published (Hosokawa et al., 2000). In this study, the authors transformed a leaf explant-derived cell suspension of $G$. triflora $\times G$. scabra using a biolistic method. The transformation parameters were examined by monitoring the transient expression of $\beta$-glucuronidase gene driven by CaMV 35S promoter. Following a two-step hygromycin $\left(30 \mathrm{mg} \cdot \mathrm{l}^{-1}\right)$ selection in liquid and agar-solidified media, putative transformed calli were obtained and only two transgenic gentian plants were regenerated from two selected callus lines. PCR analysis and Southern blot revealed stable integration of the reporter gene (Hosokawa et al., 2000).

In this paper, we present the transformation of three suspensions characterized by morpho- and embryogenic potential using $A$. tumefaciens $\mathrm{C} 58 \mathrm{C} 1$ strain carrying a pDraGON-G:GFP vector together with a helper plasmid pCH32 in the presence of the amino acid L-glutamine. Glutamine is one of the primary amino acids formed by nitrogen assimilation and often the most abundant amino acid found in plants (Young et al., 2010). L-glutamine works in two ways: firstly by increasing the efficiency of transformation and protecting Agrobacterium cells against the negative effect of plant-derived polyphenols and secondly by protecting the ability of bacteria to transfer fragments of T-DNA (Sandal et al., 2007). Amino acid inactivates the quinones, or the oxidized products of polyphenols, through replacement of its nitrogen atom by one of the oxygen atoms of quinones, thereby preventing their harmful effects (Kumar et al., 2013).

In our experiments, L-glutamine showed statistically significant effects on the transient expression of the studied cell suspensions. It was found to be an indispensable factor for the stable expression of transgenes in gentian tissues and plants. The concentrations of 0.5 and $1 \mathrm{~g} \cdot \mathrm{l}^{-1}$ of L-glutamine significantly influenced the transformation of all the three investigated cell suspensions. Thus, our results confirmed the findings of other studies which showed the importance of application of L-glutamine for achieving successful transformation of Camellia sinensis (tea), a plant that copiously produces secondary metabolites and polyphenols (Sandal et al., 2007; Mondal et al., 2001). In the case of $G$. lutea and G. cruciata, 0.5 and $1 \mathrm{~g} \cdot 1^{-1}$ L-glutamine seemed effective for improving transformation efficiency (Sandal et al. 2007; Mondal et al. 2001). In the case of G. kurroo, the transformation efficiency increased with the increase in the concentration of L-glutamine. At the concentration of $2 \mathrm{mg} \cdot \mathrm{l}^{-1}$ of L-glutamine, a difference in the response of the suspensions was observed which was evident from their morphogenic potential, with $G$. kurroo showing a higher morphogenic potential.

Conversely, a transformation study of barley microspores showed that glutamine did not enhance the transformation efficiency of $A$. tumefaciens, and surprisingly, it was not required during the 2 days of co-culture during which the androgenetic development of microspores took place (Kumlehn et al., 2006). The application of other factors known to be increasing transformation efficiency, such as ascorbic acid, glutathione, and tocopherol, was totally unsuccessful in our study (data not shown). In addition, we did not examine the function of ACET $\left(20 \mathrm{mg} \cdot \mathrm{l}^{-1}\right)$ as an obligatory factor for Agrobacterium transformation in the present study (Palmer and Shaw, 1992).

For all the three cell suspensions studied, $48 \mathrm{hrs}$ of incubation with $A$. tumefaciens $\mathrm{C} 58 \mathrm{C} 1$ appeared to be optimal for obtaining the greatest number of transformed cell aggregates when TIM was added to the culture. TIM is a bacteriocidal agent and prevents Agrobacterium from overgrowing on cells. In the case of $\mathrm{G}$. $\mathrm{cru}$ ciata, a cell suspension-derived transgenic line was regenerated following only $24 \mathrm{hrs}$ of incubation. However, statistical analysis of the primary results indicated that 48-hr incubation of cell suspension was preferable. In contrast to other transformation systems, which are based on tissue wounding and subsequent production of phenolic compounds and sugars (Cangelosi et al., 1990), cell suspensions, without being wounded, required a longer incubation period and a longer duration of TIM treatment for the elimination of bacterial contamination. Likewise, cell suspensions of Arabidopsis thaliana were also co-cultured (shaken) with bacteria for $48 \mathrm{hrs}$ (Gallego et al., 1999), but Nicotiana tabacum required as much as $72 \mathrm{hrs}$ of incubation (Rempel and Nelson, 1995). The conditions necessary for Agrobacterium transformation of embryogenic cell suspension cultures appeared to be improved by the absence of phenols and 
sugars (natural attractants of bacteria) derived from the transformed plant cells from the cultures, while ACET was the only extraneous factor that induced bacterial virulent genes thereby improving transformation (Palmer et al., 1992; Cangelosi et al., 1990). In this respect, the ultrastructure of embryogenic cell suspension aggregates revealed that the cell wall of external cells of an aggregate was several times thicker than the one formed between daughter cells inside the aggregate (Mikuła et al., 2005). Our results showed that L-glutamine plays an important role like other amino acids (e.g., L-proline) that are used in plant cell manipulation or for cellular protection against stress (Liang et al., 2013). Thus, the relatively short list of species which are known to be transformed by $A$. tumefaciens with the help of embryogenic cell suspension is extended by the three species of gentians studied here. It is noteworthy that although we produced many cell aggregates expressing uidA gene and showing resistance to kanamycin, and observed numerous structures indicative of advanced embryogenesis, our experiments did not produce a large number of T0 transformants; in fact, we regenerated only a few transformants. Thus, we would like to formulate a hypothesis that this relatively simple type of transformation involving a relatively noncomplex "classical plasmid" reduced the embryogenic potential of cell suspensions of the gentian species investigated. It was not a case of optimal post-transformation culture conditions, but rather a case of the numerous treatments that were associated with the transformation procedure, as well as the morphogenic potential of the cells. Somatic embryogenesis occurred more rarely in the cell suspensions investigated than in the wild-type suspensions. The results presented here support the recently published data concerning the nonvector protoplast transformation system. Based on the application of the same plasmid electroporation in the protoplast transformation of embryogenic cell suspensions of $G$. kurroo and regeneration of T0 transformants (Wójcik and Rybczyński, 2015), it appears that the embryogenic characteristics of gentians are very gentle and sensitive to their genome modifications.

\section{Conclusions}

By using $A$. tumefaciens strain $\mathrm{C} 58 \mathrm{C} 1$ carrying $n p t I I$ and uidA genes, we transformed embryogenic cell lines of three species of gentians ( $G$. lutea, G. cruciata, G. kur- roo). Transgenic lines were selected using $50 \mathrm{mg} \cdot \mathrm{l}^{-1}$ kanamycin and analyzed for $\beta$-glucuronidase expression. Only one of the three lines of $G$. cruciata showed the potential of somatic embryo regeneration. Some embryos were able to reach the germling stage and developed into T0 plantlets. All the experiments indicated that L-glutamine at a concentration $1.0 \mathrm{~g} \cdot \mathrm{l}^{-1}$ was crucial for improving the transformation efficiency. At the L-glutamine concentration of $2.0 \mathrm{~g} \cdot 1^{-1}$, a difference in the response of cell suspension of the studied species was observed. Taken together, we conclude that the in vitro embryogenesis of the studied gentians is very sensitive to genome modification and the treatments involved in the transformation procedure.

\section{Acknowledgments}

This research was supported financially by the Polish Government project No. N302 139035. The first author would like to extend her thanks to Prof. Jan Szopa-Skórkowski for his constructive comments relating to plant molecular biology.

\section{Authors' contributions}

AIW conducted the laboratory experiments. JJR wrote the manuscript.

\section{References}

Amstrong C.L., Green C.E. (1985) Establishment and maintenance of friable, embryogenic maize callus and the involvement of the L-proline. Planta 164: 207-214.

Barešová H., Kaminek M. (1984) Light induced somatic embryogenesis in suspension cultures of Centaurium erythraea. [in:] Plant Tissue and Cell Culture Application to Crop Improvement. Proceedings of the International Symposium Olomouc, Czechoslovakia. Eds. Novak F.J., Havel L., Doležel J. pp: 163-164.

Cangelosi G.A., Ankenbauer R.G., Nester E.W. (1990) Sugars induce the Agrobacterium virulence genes through a periplasmic binding-protein and a transmembrane signal protein. Proc. Natl Acad. Sci. USA. 87: 6708-6712.

Carlos-Hilario L.R., Christopher D.A. (2015) Improved Agrobacterium-mediated transformation of Carica papaya cultivar 'Kapoho' from embryogenic cell suspension cultures. In Vitro Cell Dev. Biol.-Plant. 51: 580-587.

Chee Wong W., Othman R.Y., Khalid N. (2008) Improvement in the efficiency of Agrobacterium-mediated transformation of embryogenic cell suspension of banana cv.'Mas' using a low-antibiotic liquid washing-assisted approach. Transgenic Plant J. 2: 75-85.

Chong-Rerez B., Reyes M., Rojas L., Ocana B., Perez B., Kosky R.G., Angenon G. (2012) Establishment of embryogenic cell suspension cultures and Agrobacterium-mediated transformation in banana cv. 'D warf Cavendish' (Musa $A A A)$ : effect of spermidine and transformation efficiency. Plant Cell Tiss. Organ. Cult. 111: 79-90. 
Chowdhry C.N., Tyagi A.K., Maheshwari M., Maheshwari S.C. (1993) Effect of L-proline and L-tryptophab on somatic embryogenesis and plantlet regeneration of rice (Oryza sativa L. cv. Pusa 169). Plant Cell Tiss. Org. Cult. 32: 357-361.

Chueh F.S., Chen C.C., Sagare A.P., Tsay H.S. (2001) Quantitative determination of secoiridoid glucosides in in vitro propagated plants of Gentiana davidii var. formosana by high performance liquid chromatography. Planta Med. 67: 70-73.

Dan Y. (2008) Biological functions of antioxidants in plant transformation. InVvitro Cell Dev. Biol.-Plant. 44: 149-161.

Dong J.Z., McHughen A. (1993) An improved procedure for production of transgenic flax plant using Agrobacterium tumefaciens. Plant Sci. 88: 61-71.

Dutt M., Vansconcellos M., Grosser J.W. (2011) Effects of antioxidants on Agrobacterium-mediated transformation and accelerated production of transgenic plants of Mexican Lime (Citrus aurantifolia Swingle). Plant Cell Tiss. Organ. Cult. 107: 79-89.

Fiuk A., Rybczyński J.J. (2008) Factors influencing efficiency of somatic embryogenesis of Gentiana kurroo (Royle) cell suspension. Plant Biotech. Rep. 2: 33-39.

Fiuk A., Rybczyński J.J. (2007) The effect of several factors on somatic embryogenesis and plant regeneration in protoplast cultures of Gentiana kurroo (Royle). Plant Cell Tiss. Org. Cult. 91: 263-271.

Gallego M.E., Sirand-Pugnet P., White C.I. (1999) Positivenegative selection and T-DNA stability in Arabidopsis transformation. Plant Mol. Biol. 39: 83-93.

Garin E., Barnier-Cardou M., Isabel N., Klimaszewska K., Plourde A. (2000) Effect of sugars, amino acids and culture technique on maturation of somatic embryos of Pinus strobus on medium with two gellan gum concentrations. Plant Cell Tiss. Org. Cult. 62: 27-37.

Ganapathi T.R., Higgs N.S., Balint-Kurti P.J., Arntzen C.J., May G.D., Van Eck J.M. (2001) Agrobacterium-mediated transformation of embryogenic cell suspensions of the banana cultivar Rasthaki (AAB). Plant Cell Rep. 20: 157-162.

Gerdakaneh M., Mozafari A.A., Adel sioseh-mardah, Sarabi B. (2011) Effects of different amino acids on somatic embryogenesis of strawberry (Fragaria $x$ ananassa Duch.). Acta Physiol. Plant. 33: 1847-1852.

Ghosh A., Ganapathi T.R., Nath P., Bapat V.A. (2009) EStablishment of embryogenic cell suspension cultures and Agrobacterium-mediated transformation in an important Cavendish banana cv. Robusta (AAA). Plant Cell Tiss. Organ Cult. 97: 131-139.

Hamilton C.M. (1997) A-binary-BAC system for plant transformation with high-molecular weight DNA. Gene 200.

Haroun S.A., Shukry W.N., El-Sawy O. (2010) Effect of asparagine or glutamine on growth and metabolic changes in Phaseolus vulgaris under in vitro conditions. Biosci. Res. 7: 1-21.

Hosokawa K., Matsuki R., Oikawa Y., Yamamura S. (2000) $A d$ ventitious shoot regeneration from leaf, stem and root explants of commercial cultivars of Gentiana. Plant Cell Rep. 15: 578-581.
Hosokawa K., Matsuki R., Oikawa Y., Yamamura S. (2000) Production of transgenic gentian plants by particle bombardment of suspension-culture cells. Plant Cell Rep. 19: 454-458.

Huang X., Huang X., Xiao W., Zhao J., Dai X., Chen Y., Li X. (2007) Highly efficient Agrobacterium-mediated transformation of embryogenic cell suspensions of Musa acuminata cv. Mas (AA) via a liquid co-cultivation system. Plant Cell Rep. 26: 1755-1762.

Jefferson R.A., Kavanagh T.A., Bevan M.V. (1987) GUS fusions: $\beta$-glucoronidase as a sensitive and versatile gene fusion marker in higher plants. EMBO J. 6: 3901-3907.

Ketchum R.E.B., Wherland L., Croteau R.B. (2007) Stable transformation and long-term maintenance of transgenic Taxus cell suspension cultures. Plant Cell Rep. 26: 1025-1033.

Kim Y.S., Kwon T.H., Sik Y.M. (2004) Direct transfer and expression of human GM-CSF in tobacco suspension cell using Agrobacterium-mediated transfer system. Plant Cell Tiss. Org. Cult. 78: 133-138.

Kumar N., Gulati A., Bahattacharya A. (2013) L-Glutamine and L-Glutamic Acid facilitate successful Agrobacterium infection of recalcitrant tea cultivars. Appl. Biochem. Biotech. 170(7): 10. doi: 10.1007/s12010-013-0286-z.

Kumlehn J., Seracetchinova L., Hensel G., Baker D., Loerz H. (2006) Genetic transformation of barley (Hordeum vulgare L.) via infection of androgenetic pollen cultures with Agrobacterium tumefaciens. Plant Biotech J. 4: 251-261.

Liang X., Zhang L., Natarajan S.K., Becker D.F. (2013) Proline mechanisms of stress survival. Antioxid. Redox Signal. 19: 998-1011.

Malabadi R.B., Van Staden J. (2005) Role of antioxidants and amino acids on somatic embryogenesis of Pinus patula. In Vitro Cell. Dev. Biol.-Plant. 41: 181-186.

Mikuła A., Rybczyński J.J., Skierski J., Latkowska M.J., Fiuk A. (2005) Somatic embryogenesis of Gentiana genus IV: Characterization of Gentiana cruciata and Gentiana tibetica embryogenic cell suspensions. [in:] Liquid Culture Systems for In Vitro Plant Propagation. Eds. Hvolsef-Eide A.K., Preil W. Springer: 345-358.

Mikuła A., Tykarska T., Kuraś M., Rybczyński J.J. (2005) Somatic embryogenesis of Gentiana cruciata (L.). Histological and ultrastructural changes in seedling hypocotyl explants. In Vitro Cell Dev. Biol.-Plant. 41: 686-694.

Mikuła A., Tomiczak K., Rybczyński J.J. (2011) Cryopreservation enhances embryogenic capacity of Gentiana cruciata (L.) suspension culture and maintains (epi)-genetic uniformity of regenerants. Plant Cell Rep. 30: 565-574.

Mishiba K., Nishihara M., Abe Y., Nakatsuka T., Kawamura H., Kodama K., Takesawa T., Abe J., Yamamura S. (2006) Production of dwarf potted gentian using wild-type Agrobacterium rhizogenes. Plant Biotech. 23: 33-38.

Mishiba K., Nishihara M., Nakatsuka T., Abe Y., Hirano H., Yokoi T., Kikuchi A., Yamamura S. (2005) Consistent transcriptional silencing of 35S-driven transgenes in gentian. Plant J. 44: 541-556. 
Mondal T.K., Bhattacharya A., Ahuja P.S., Chand P.K. (2001) Transgenic tea /Camellia sinensis (L.) O. Kuntze c. Kangra Jat] plants obtained by Agrobacterium-mediated transformation of somatic embryos. Plant Cell Rep. 20: 712-720.

Nakatsuka T., Abe Y., Kakizaki Y., Kubota A., Shimada N., Nishihara M. (2009) Over-expression of Arabidopsis FT gene reduces juvenile phase and induces early flowering in ornamental gentian plants. Euphytica 168: 113-119.

Nalawade S.M., Tsay H.S. (2004) In vitro propagation of some important Chinese medicinal plants and their sustainable usage. In Vitro Cell Dev. Biol.-Plant. 40: 143-154.

Nishihara M., Nakatsuka T., Hosokawa K., Yokoi T., Abe Y., Mishiba K., Yamamura S. (2006) Dominant inheritance of white-flowered and herbicide-resistant traits in transgenic gentian plants. Plant Biotech. 23: 25-31.

Palmer A.C.V., Shaw C.H. (1992) The role of VirA and VirG phosphorylation in chemotaxis towards acetosyringone by Agrobacterium tumefaciens. J. Gen. Microbiol. 138: 2509-2514.

Pawar B., Kale P., Bahunrupe J., Jadhaw A., Kale A., Panar S. (2015) Proline and glutamine improve in vitro callus induction and subsequent shooting in rice. Rice Sci. 22: 283-289.

Rempel H.C., Nelson L.M. (1995) Analysis of conditions for Agrobacterium-mediated transformation of tobacco cells in suspensions. Transgenic Res. 4: 199-207.

Ruffoni B., Massabó F. (1996) Plant production by somatic embryogenesis in cell suspension culture of Lisanthus russellianus Hook. Plant Tiss. Cult. Biotech. 4: 194-198.

Rybczyński J.J., Davey M.R., Mikuła A. (2015) The Gentianaceae: biotechnology and application vol. 2., Springer: 1-452.

Sandal I., Saini U., Lacroix B., Bhattacharya A., Ahuja P.S., Citovsky V. (2007) Agrobacterium-mediated genetic transformation of tea leaf explants: effects of counteracting bactericidity of leaf polyphenols without loss of bacterial virulence. Plant Cell Rep. 26: 169-176.

Semeria L., Ruffoni B., Rabaglio M., Genga A., Vaira A.M., Accotto G.P., Allavena A. (1996) Genetic transformation of Eustoma grandiflorum by Agrobacterium tumefaciens. Plant Cell Tiss. Org. Cult. 47: 67-72.

Semeria L., Vaira A.M., Accotto G.P., Allavena A. (1995) Genetic transformation of Eustoma grandiflorum Griseb. by microprojectile bombardment. Euphytica 85: 125-130.

Shekhawat U.K.S., Ganapathi T.R., Srinivas I., Bapat V.A., Rathore T.S. (2008) Agrobacterium-mediated genetic trans- formation of embryogenic cell suspension cultures of Santalum album L. Plant Cell Tiss. Org. Cult. 92: 261-271.

Shetty K., McKersie B.D. (1993) Proline, thioproline and potassium mediated stimulation of somatic embryogenesis in alfalfa (Medicago sativa L.). Plant Sci. 88: 185-193.

Sun S.B., Meng L.S. (2010) Genetic transformation of Gentiana dahurica Fisch by Agrobacterium tumefaciens using zygotic embryo-derived callus. Acta Physiol. Plant. 32: 629-634.

Tomiczak K., Mikuła A., Rybczyński J.J. (2015) Protoplast culture and somatic cell hybridization of gentians. [in:] Gentianaceae: biotechnology and application, vol. 2. Eds. Rybczyński J.J., Davey M.R., Mikuła A. Springer: 163-185.

Tomiczak K., Sliwinska E., Rybczyński J.J. (2017) Protoplast fusion in the genus Gentiana: genomic composition and genetic stability of somatic hybrids between Gentiana kurroo Royle and G. cruciata L. Plant Cell Tiss. Organ. Cult. 131: 1-14.

Wilson S.A., Keen P., McKee M.C., Raia N., VanEck J., Roberts S. (2018) Development of an Agrobacterium-mediated fransgformation method for Taxus suspension cultures. In Vitro Cell. Develop. Biol.-Plant 54: 36-44.

Wójcik A., Rybczyński J.J. (2015) Electroporation and morphogenic potential of Gentiana kurroo (Royle) embryogenic cell suspension protoplast. BioTechnologia 96: 19-29.

Wójcik A., Rybczyński J.J. (2017) Genetic transformation of gentian Gentiana tibetica (King) leaf explants with Agrobacterium tumefaciens strain C58C1. Acta Physiol Plant. 39: 29.

Wu H., McCormac A.C., Elliott M.C., Chen D.F. (1998) Agrobacterium-mediated stable transformation of cell suspension cultures of barley (Hordeum vulgare). Plant Cell Tiss. Org. Cult. 54: 161-171.

Xiang C., Han P., Lutziger I., Wang K., Olivier D.J. (1999) A mini binary vector series for plant transformation. Plant Mol. Biol. 17: 711-717.

Yang H., Bogner M., Stierhof Y.-D., Ludewig U. (2010) H+independent glutamine transport in plant root tips. PLoS One 5(1): e8917.

Zouine J., Hadrami I.E. (2007) Effect of 2,4-D, glutamine and $B A P$ on embryogenic suspension culture of date palm (Phoenix dactylifera L.). Sci. Hort. 112: 221-226. 